\title{
Dwa spojrzenia na historię Polski. Polemika demokratów lwowskich Henryka Schmitta i Ludwika Wolskiego z przedstawicielem krakowskiej „nowej szkoły historycznej” Józefem Szujskim w latach 70. XIX wieku
}

Zarys treści: Celem artykułu jest omówienie polemiki, do której doszło w latach 70. XIX w. między reprezentantami demokratycznych poglądów na dzieje Polski Henrykiem Schmittem i adwokatem Ludwikiem Wolskim a głównym przedstawicielem „nowej szkoły historycznej” Józefem Szujskim. Charakteryzując przebieg i okoliczności owej polemiki, staram się odpowiedzieć na pytanie, czy była ona jedynie sporem historiograficznym oraz czy położenie polityczne Galicji i sytuacja osobista każdego $\mathrm{z}$ autorów miała wpływ na ich poglądy?

The outline of the content: The purpose of the article is to present the polemic between Henryk Schmitt and Ludwik Wolski, the advocates of what is known as a democratic view of Polish history, on the one hand, and one of the main representatives of the Kraków school of history, Józef Szujski, on the other. In recounting the polemic, I seek to answer the question of whether it was simply a matter of historiographical controversy, or whether Galicia's political circumstances and the situation of the subjects of this article affected the views they expressed.

Słowa kluczowe: historiografia polska, szkoła lelewelowska, szkoła krakowska, spór o powstanie styczniowe, polityka stańczyków, Józef Szujski, Henryk Schmitt, Ludwik Wolski

Keywords: Polish historiography, the Lelevel school of history, the Kraków school of history, dispute over the January Uprising, politics of Stanczyks, Józef Szujski, Henryk Schmitt, Ludwik Wolski

Upadek powstania styczniowego przyniósł w społeczeństwie polskim odwrót od dążeń niepodległościowych. Rozczarowanie nieudanym zrywem skłoniło część niedawnych zwolenników irredenty do przystąpienia do przeciwnego kolejnym powstaniom obozu konserwatystów galicyjskich. W gronie tym znalazł się historyk Józef Szujski, działacz konspiracyjny z czasów powstania styczniowego, który tworząc czterotomowe Dzieje Polski (1862-1866), dał się poznać jako zwolennik romantycznej wizji historii ojczystej. W 1866 r. w Krakowie Szujski założył wraz ze Stanisławem 
Tarnowskim, Stanisławem Koźmianem i Ludwikiem Wodzickim miesięcznik „Przegląd Polski”, na łamach którego opublikował polityczny program konserwatystów krakowskich (Kilka prawd z dziejów naszych. Ku rozważeniu w chwili obecnej, 1867) oraz satyry polityczne Teka Stańczyka, od których pochodzi nazwa stronnictwa. Artykuły polityczne ugruntowały pozycję Szujskiego jako jednego z przywódców stańczyków, głoszących lojalizm wobec władzy austriackiej. Pogląd na bieżącą politykę działaczy stronnictwa konserwatywnego znajdował odzwierciedlenie w ich spojrzeniu na historię Polski. Stworzona przez nich tzw. nowa szkoła historyczna zwracała się przeciwko romantycznej koncepcji dziejów Polski, wiązanej przede wszystkim z nazwiskiem Joachima Lelewela. Wspólnym założeniem przedstawicieli nowej szkoły było przekonanie o „anarchicznym charakterze narodowym” Polaków. Reprezentanci szkoły krakowskiej starali się poprzez zmianę spojrzenia na przeszłość Polski upowszechnić własną wykładnię historii, której istotę stanowiła krytyka i odrzucenie koncepcji szkoły lelewelowskiej jako „historii fałszywej”. Założeniom tym odpowiadała nowa synteza Szujskiego, która ukazała się w 1880 r. pt. Historii polskiej treściwie opowiedzianej ksiag dwanaście. Na tle przedstawicieli „nowej szkoły historycznej" jej autor wyróżniał się tym, że jako jedyny przeszedł wyraźną ewolucję poglądów od republikanizmu do „ugodowego monarchizmu”, choć jednocześnie zachował szacunek do samej idei powstania styczniowego i jego ofiar ${ }^{1}$.

Wystąpienie polityczne stańczyków oraz ich atak skierowany przeciw tradycjom niepodległościowym, w tym głównie przeciw powstaniu styczniowemu, spotkały się z krytyką środowiska demokratów lwowskich² ${ }^{2}$ którzy kierunek „nowej szkoły historycznej” oceniali z perspektywy demokratycznych poglądów na przeszłość Polski. Jako jeden z pierwszych dokonał tego przebywający wówczas w Paryżu Ludwik Wolski, publikując w wydanym we Lwowie Albumie Muzeum Narodowego w Rapperswyllu w 1876 r. artykuł pt. Diagnoza $a^{3}$.

${ }^{1}$ A. Wierzbicki, Józef Szujski (1835-1883), w: tenże, Poczet historyków polskich. Historiografia polska doby podzaborowej, Poznań 2014, s. 101-107; tenże, Wschód - Zachód w koncepcjach dziejów Polski. Z dziejów polskiej myśli historycznej w dobie porozbiorowej, Warszawa 1984, s. 192; tenże, Historiografia polska doby romantyzmu, Wrocław 1999, s. 449-350; J. Maternicki, Historia i życie narodu. Poglądy i postawy historyków polskich XIX i XX w., Rzeszów 2009, s. 144-146; J. Adamus, Syntezy historyczne Szujskiego, w: Studia historyczne ku czci Stanisława Kutrzeby, t. 2, Kraków 1938, s. 15.

${ }^{2}$ Przedstawiona w niniejszym artykule polemika Ludwika Wolskiego i Henryka Schmitta z Józefem Szujskim poprzedziła krytyczne głosy wobec historycznej polityki stańczyków m.in. Tadeusza Romanowicza z 1882 r. oraz późniejszą głośną debatę o powstaniu styczniowym z lat 90. XIX w., skupioną głównie wokół dzieła Stanisława Koźmiana Rzecz o roku 1863; zob. L. Michalska-Bracha, Powstanie styczniowe w pamięci zbiorowej społeczeństwa polskiego w okresie zaborów, Kielce 2003; taż, Między pamięcia a historiografią. Lwowskie debaty o powstaniu styczniowym (1864-1939), Kielce 2011; T. Romanowicz, Polityka Stańczyków. Odpowiedź na refer[at] Leona Bilińskiego „O stronnictwie Stańczyków”, Kraków 1882; A. Wierzbicki, Wokół „czarnej legendy” historiografii krakowskich konserwatystów, „Kwartalnik Historyczny” 104, 1997, nr 2, s. 63-87.

3 L. Wolski, Diagnoza, w: Album Muzeum Narodowego w Rapperswyllu, red. J.I. Kraszewski, Lwów 1876, s. 247-294. 
Autor owego artykułu był adwokatem od lat związanym z lwowskim środowiskiem demokratycznym. Wraz z Mieczysławem Romanowskim należał do grona młodych literatów określanych w literaturze mianem „przedburzowców”4. Od końca lat 50. XIX w. Wolski współpracował z „Dziennikiem Literackim” Jana Dobrzańskiego oraz pismem dla ludu „Dzwonek” Brunona Bielawskiego, w których artykuły historyczne i poematy zamieszczał także Józef Szujski. W $1870 \mathrm{r}$. został wybrany do Sejmu Krajowego Galicji III kadencji (1870-1873), a następnie w 1877 r. do wiedeńskiej Rady Państwa ${ }^{5}$. W Kole Polskim w Wiedniu należał do mniejszościowego ugrupowania liberalno-demokratycznego. W listopadzie $1878 \mathrm{r}$., w czasie debaty ratyfikacyjnej w Radzie Państwa wystąpił z Ottonem Hausnerem przeciwko okupacji Bośni i Hercegowiny przez Austro-Węgry. Konserwatywni posłowie w Kole Polskim, którzy początkowo razem z liberałami sprzeciwiali się okupacji Bośni i Hercegowiny, ostatecznie poparli politykę rządu wiedeńskiego. Posłowie liberalni, krytykując konserwatystów za zbyt słabą obronę polskich interesów, zażądali zmiany statutu Koła Polskiego w taki sposób, by mogli na forum parlamentu zabierać głos odrębny wobec stanowiska klubu. $Z$ powodu sprzeciwu większości członków Koło opuściło trzech posłów, wśród nich Ludwik Wolski. W swoim wystąpieniu na forum parlamentu przestrzegał rząd austriacki przed prowadzeniem nierozważnej polityki na Bałkanach, argumentując, że administrowanie częścią Imperium Ottomańskiego przybliżało konflikt z Rosją

Swoją Diagnozę Wolski napisał jeszcze w lipcu 1876 r., a więc w apogeum konfliktu na Bałkanach. Antytureckie powstanie w Bośni i Hercegowinie stanowiło jednak tylko pretekst do dyskusji na temat niedawnego powstania w Polsce ${ }^{7}$. Rzeczywistym powodem wystąpienia Wolskiego było bowiem jego przekonanie o zwiększającym się od klęski powstania styczniowego upadku moralnym

${ }^{4}$ Określenie „przedburzowcy”, charakteryzujące pokolenie literatów tworzących przed „burzą" powstania styczniowego, wprowadził do literatury naukowej Janusz Maciejewski. Sam termin pochodzi z wiersza Mieczysława Romanowskiego pt. Żegnaj z 1857 r.; zob. J. Maciejewski, Przedburzowcy. Z problematyki przełomu między romantyzmem a pozytywizmem, Kraków 1971.

${ }^{5}$ Ludwik Wolski (1835-1887) został wybrany do wiedeńskiej Rady Państwa dwukrotnie: na V kadencję (1873-1879) na miejsce Franciszka Smolki (który zrezygnował z mandatu w 1877 r.) oraz na VI kadencję (1879-1885), zrezygnował z mandatu w $1883 \mathrm{r}$.

${ }^{6}$ Mowy Ludwika Wolskiego i Ottona Hausnera dnia 4. $i$ 5. listopada 1878 w parlamencie austriackim, wyd. 2, Lwów 1879, s. 14-16; por. J. Buszko, Polacy w parlamencie wiedeńskim 1848-1918, Warszawa 1996, s. 92-96. Szerzej o sprawie polskiej w okresie kryzysu wschodniego lat 1875-1878 zob. Historia dyplomacji polskiej, t. 3, red. L. Bazylow, Warszawa 1982, s. 715-725 (rozdział autorstwa J. Zdrady); H. Wereszycki, Walka o pokój europejski 1872-1878, Warszawa 1971.

${ }^{7}$ Przewidując, że w przypadku zwycięstwa Czarnogórcy będą sławić swoje powstanie, w razie klęski zaś nazwą je pewnie „zbrodniczym szaleństwem”, Wolski nawiązywał do słów Juliana Klaczki z opublikowanego w 1875 r. studium o dwóch kanclerzach (Aleksandrze Gorczakowie i Ottonie Bismarcku), które świadczyło o zmianie poglądów dawnego współpracownika Agenta Głównego Rządu Narodowego z 1864 r.; zob. J. Klaczko, Deux chanceliers, III L'action commune, „Revue des deux Mondes" 10, 1875, s. 751. 
w Galicji ${ }^{8}$. Powołując się na popularnego we Lwowie poznańskiego demokratę i filozofa mesjanistycznego Karola Libelta ${ }^{9}$, Wolski porównał śmierć polityczną ze śmiercią dziejową narodu. Ta pierwsza, wywołana przez rozbiory, sama w sobie nie musiała jeszcze oznaczać śmierci całkowitej, czyli dziejowej. Tej ostatniej, zdaniem Wolskiego, Polska jednak nie doznała, ponieważ zachowała ciągłość historyczną i jedność narodową. Świadomy swojej przeszłości naród polski nie przestał się rozwijać, mimo podziału kraju wciąż powstawała literatura i poezja narodowa ${ }^{10}$. Nie była to jednak sytuacja nieodwracalna. Autor Diagnozy zwracał uwagę na rosnący zanik więzi między zaborami i „upadek ducha” wśród polskiej inteligencji, która powinna nadawać kierunek narodowej kulturze ${ }^{11}$. Pod tym względem jego szczególny niepokój budziły działania stronnictwa stańczyków.

Wśród „rozważniejszych działaczy” owego stronnictwa klęska powstania styczniowego wywołała bowiem zwrot, który Wolski odczytywał jako ruch w kierunku ośmieszania narodowej insurekcji. Wolski przekonywał, że dokonując rozliczeń pod hasłem „zbawiennej reakcji”, sami Polacy uczynili wszystko to, czego nie mogli dokonać zaborcy. Za najbardziej niebezpieczne uznawał potępienie w historii Polski tych działań na rzecz wolności i tolerancji religijnej, które służyły narodowi do umocnienia wiary w swoje posłannictwo i woli przetrwania ${ }^{12}$.

Warto podkreślić, że Wolski nie odmawiał konserwatystom dobrych intencji i patriotyzmu. W stronnictwie konserwatywnym dostrzegał osoby szczerze kochające kraj, ale podążające za obcymi hasłami. Przypuszczał, że jedynie zeszli oni na manowce, a duma nie pozwalała im przyznać się do błędu. W poglądach historycznej szkoły krakowskiej nie dostrzegał nowego spojrzenia na narodową przeszłość, ponieważ krytyczna metoda badań historycznych i teza o upadku Polski z powodu win własnych istniały jeszcze przed wystąpieniem stańczyków ${ }^{13}$. Wolski uznawał wprawdzie potrzebę badania przeszłości narodu bez względu na jego aktualne położenie, jednak w enuncjacjach uczonych szkoły krakowskiej dostrzegał namiętności stanowiące dowód, że chodziło im nie o prawdę naukową, lecz o cel polityczny ${ }^{14}$.

8 L. Wolski, Diagnoza..., s. 247.

9 Karol Fryderyk Libelt (1807-1875) - polski filozof mesjanistyczny, działacz polityczny i społeczny, w latach 1868-1875 prezes Poznańskiego Towarzystwa Przyjaciół Nauk. Jego przyjazd do Lwowa w kwietniu 1869 r. na zaproszenie Towarzystwa Naukowo-Literackiego „Gazeta Narodowa” określiła mianem demonstracji ludowej. Libelta, mieszkańca Wielkopolski, witano we Lwowie jako reprezentanta idei narodowej łączącej wszystkie zabory. W czasie pobytu we Lwowie Libeltowi nieodłącznie towarzyszył Schmitt, obaj poznali się w Berlinie w 1862 r.; zob. W. Hahn, Karol Libelt we Lwowie w roku 1869, Lwów 1907.

${ }^{10}$ L. Wolski, Diagnoza..., s. 249.

11 Tamże, s. 250.

12 Tamże, s. 253.

13 Tamże, s. 254-256; Wolski nie wyjawił niestety, jakich prekursorów szkoły krakowskiej miał na myśli.

${ }^{14}$ Tamże, s. 257. 
Zdaniem Wolskiego było nim przyjęcie zachodniej doktryny legitymizmu, z równoczesnym odrzuceniem pojęcia demokracji.

Wątpiących we wpływ rozumienia przeszłości na przyszłość narodu przekonywał, że potępiając liberum veto, trzeba będzie potępić wszystko co do niego doprowadziło, czyli sięgającą XIV w. tradycję zabezpieczania wolności osobistej przed nadużyciami władzy królewskiej. W ten sposób stanowiące największą chlubę Polski dążenie do wolności stałoby się odtąd jej głównym oskarżeniem, a naród straciłby swoją najważniejszą zasługę dziejową.

Ten argument historiozoficzny Wolski łączył z odwołaniem się do społecznego wymiaru historii. Jego zdaniem należało pielęgnować ideę, która wiążąc przeszłość z teraźniejszością, stanowiłaby wciąż aktualną podstawę dziejów i bytu narodu polskiego. Wbrew dopiero co złożonej deklaracji o potrzebie badania przeszłości w każdych warunkach historycznych podkreślał więc w tym kontekście, że historycy nie powinni przedstawiać ogółowi społeczeństwa krytyki narodowej historii, ponieważ społeczeństwo w podejściu do przeszłości bardziej kierowało się uczuciami niż rzeczową oceną. Właśnie z tej perspektywy autor Diagnozy wskazywał na konsekwencje poglądów historycznych szkoły krakowskiej.

Jego zdaniem upowszechnienie teorii „nowej szkoły historycznej” doprowadziłoby do utraty wspólnotowego wymiaru historii: z punktu widzenia ludu historia przestałaby być historią wspólną, stałaby się historią samej warstwy szlacheckiej. Historycy nowej szkoły, chociaż powodowani patriotyzmem, prezentowali zdaniem Wolskiego „rosyjskie” poglądy na historię Polski. Mieli odrzucać tradycje narodowe, w tym nawet poezję Juliusza Słowackiego, która podważała ich poglądy na przeszłość narodu. Z tego względu autor Diagnozy odmawiał ich „prawdzie historycznej" legitymacji i sprzeciwiał się przejęciu przez ich stronnictwo władzy nad narodową pamięcią historyczną ${ }^{15}$. Krytykę narodu za jego przeszłość uważał za bezzasadną. Owszem, należało wziąć odpowiedzialność za przeszłość i własne winy, ale także pogodzić się z tym, że inne dzieje narodu nie były możliwe. Narodu polskiego nie powinno się krytykować za brak silnego rządu, skoro za najważniejszą wartość uznawał wolność obywatelską, o czym świadczyło prawne zagwarantowanie wolności osobistej w Polsce już w 1430 r. Wolski kwestionował zarazem pogląd, że brak silnego rządu w Polsce był najważniejszą i jedyną przyczyną jej upadku' ${ }^{16}$.

Przyczynę tę Wolski dostrzegał w położeniu geograficznym oraz w braku poczucia narodowego. Dowodził tego np. przebieg powstania kościuszkowskiego, gdy pomimo objęcia rewolucją trzech stolic (Krakowa, Warszawy i Wilna) Kościuszce nie udało się uzbroić całego narodu. W państwie przewodziła szlachta, która wolność i równość wywalczyła tylko dla siebie, a pozbawiona dopływu świeżej

15 Tamże, s. 258-261.

16 Tamże, s. 262-263. 
(społecznej) krwi skończyła w sposób typowy dla każdej oligarchii: „Dzięki temu pierworodnemu grzechowi doszedł naród szlachecki do tego, że umiał w sto tysięcy koni stanąć na rokoszowym polu, a nieprzyjacielowi dał się brać i wiązać...” ${ }^{\prime 1}$.

Zdaniem Wolskiego przeciwko konserwatywnej wizji dziejów narodowych przemawiały także względy praktyczne. Uważał bowiem, że poglądy stańczyków na przeszłość Polski miały charakter czysto teoretyczny i nie stwarzały żadnej perspektywy dla działania politycznego. Mogły przekonać jedynie tę część społeczeństwa, która w 1863 r. z niechęcią pomagała powstańcom. Demokraci natomiast $\mathrm{w}$ jego mniemaniu proponowali taką wizję narodowej przeszłości, która dawała się przełożyć na działania w obszarze życia politycznego. Miała to być mianowicie wizja koncyliacyjna, stwarzająca szansę pojednania warstw ludowej i szlacheckiej. Przyznawała szlachcie zasługę dziejową, jej degenerację tłumaczyła prawami historii, ale dawała też możliwość naprawienia win w przyszłości. Wolski przestrzegał jednak szlachtę przed słuchaniem demagogów, którzy roztaczali widmo przewrotu społecznego, podczas gdy Polsce zagrażały obecnie nie ,teorie antysocjalne", lecz brak oświaty. Zwracając się z kolei w stronę ludu polskiego, Wolski twierdził, że nie miał on prawa zrzucać na szlachtę całej odpowiedzialności za własne zniewolenie. „Nikt nigdy nie uzyskał wolności w podarunku, lecz albo zasługiwał na nią, albo brał ją przemocą"18. Lud powinien albo wywalczyć sobie wolność, albo bez pozwolenia szlachty wziąć udział w obronie kraju. Taki pogląd miał rozkładać winę po obu stronach i dawać szansę na poprawę w przyszłości. Ukazywał ponadto jedność narodową ponad podziałami społecznymi ${ }^{19}$.

$\mathrm{Z}$ tą koncyliacyjną wizją przeszłości jako podstawą narodowego pojednania korespondowała odżegnująca się od rewolucji koncepcja demokracji. Wolski proponował, by Polacy, nauczeni doświadczeniem ostatniego powstania, wzięli przykład z Francji, gdzie po upadku Komuny Paryskiej w 1871 r. demokraci zaczęli odchodzić od metod rewolucyjnych, jednocześnie nie odrzucając zasad demokratycznych z 1789 r. Francuzi wykazali się mądrością polityczną, ponieważ utrzymali ciągłość tradycji republikańskiej ${ }^{20}$. Wierność demokratycznej tradycji uzupełniał krytyką galicyjskiego konserwatyzmu.

W praktyce stronnictwa stańczyków Wolski dostrzegał bezwiedne odsuwanie się od narodu i wzywał krakowskich polityków do zawrócenia z fałszywej drogi lojalizmu i ultramontanizmu. Uważał, że Polacy płacą zbyt dużą cenę za chwilowe korzyści płynące z lojalizmu. Krytykując brak polskiej inicjatywy w pracach parlamentu wiedeńskiego, wskazywał, że „za alians o wątpliwej wartości, za uśmiech ministra, za jakąś koncesję odwołalną i częstokroć w dalszem następstwie odwoływaną, gotowiśmy w każdej chwili wejść w kompromis ze swoim sumieniem,

17 Tamże, s. 265.

18 Tamże, s. 266.

19 Tamże.

20 Tamże, s. 271-273. 
popaść $\mathrm{w}$ sprzeczność $\mathrm{z}$ wielkimi zasadami, w niekonsekwencję z własną przeszłością"21. Z kolei ultramontanizm uznawał za doktrynę, która rozwijała sztandar katolicyzmu „obok Polski, czy raczej ponad Polską", a więc oddawała prymat względom innym niż narodowe. Dostrzegał w nim także zagrożenie dla polskiej tradycji wolności sumienia i religii, którą oczywiście wywodził od aktu konfederacji warszawskiej $1573 \mathrm{r} .^{22}$ Przestrzegał, że ultramontańskie stronnictwo stanowi w Polsce zagrożenie dla katolicyzmu na równi z Rosją czy Prusami. Co jednak szczególnie ciekawe, konserwatyzm krakowski nie był w oczach Wolskiego konserwatyzmem sensu stricto, a wręcz nabierał cech rewolucji. Lwowski publicysta podkreślał bowiem, że konserwatyzm stańczyków miał działanie niszczące, a nie konserwujące. Zamiast bowiem pielęgnować moralną łączność z przeszłością i odrębność charakteru narodowego, stańczycy dążyli do zerwania z piętnowaną tradycją. W miejsce tak pojętego konserwatyzmu Polska potrzebowała polityki naprawczej, restaurującej, którą jednak należało dopiero wytworzyć. Zdaniem Wolskiego miała to być polityka wierna ideałom i zarazem praktyczna (ale nie wąsko utylitarna) ${ }^{23}$. Tylko ona pozwoliłaby wychować pokolenie czynu, jednocześnie rozumne i wierzące w idee. Wolski argumentował, że jest to jedyna recepta na uniknięcie nierozważnych zrywów w przyszłości. Nie wątpił bowiem, że do jakichś zrywów dojdzie, bo „nigdy przecież w takim jak nasz narodzie nie zabraknie ludzi gorących, niezadowolnionych życiem ślimaczem, a lgnących natomiast do tego co jest wielkodusznem"24. Za niebezpiecznych uznawał więc polityków, którzy nie znając własnego narodu, próbowali zmienić go i „z gorącokrwistego uczynić zimnokrwistym"25. Dystansując się (jak już wiemy) od metod rewolucyjnych, za najlepsze rozwiązanie $\mathrm{w}$ istniejącej sytuacji Wolski uznawał więc połączenie pracy organicznej z ideą narodową ${ }^{26}$.

Tak zasadnicza krytyka założeń „nowej szkoły historycznej” doczekała się odpowiedzi jej głównego przedstawiciela. W numerze wrześniowym z 1877 r. krakowskiego „Przeglądu Polskiego” Józef Szujski replikował Wolskiemu artykułem O fałszywej historii jako mistrzyni fałszywej polityki, który stanowił deklarację ideową stronnictwa stańczyków, a po latach wszedł do kanonu polskiej publicystyki historycznej ${ }^{27}$.

${ }^{21}$ Tamże, s. 284.

22 Tamże, s. 294.

23 Tamże, s. 275.

24 Tamże, s. 276.

25 Tamże, s. 278.

26 Tamże.

27 J. Szujski, O fałszywej historii jako mistrzyni fałszywej polityki, w: M.H. Serejski, Historycy o historii. Od Adama Naruszewicza do Stanisława Kętrzyńskiego, t. 1: 1775-1918, Warszawa 1963, s. 275-298; tytuł tego artykułu został wykorzystany przez H. Michalaka jako tytuł antologii tekstów J. Szujskiego, O fałszywej historii jako mistrzyni fałszywej polityki. Rozprawy i artykuły, wybór, oprac. i wstęp H. Michalak, Warszawa 1991; por. M.H. Serejski, Zarys historii historiografii polskiej, 
Odpowiadając autorowi Diagnozy, Szujski rozprawiał się w tekście O fałszywej historii ze swoimi demokratycznymi ideałami. W wolności uznawanej przez romantyków za „zasadę” dziejów Polski dawny konspirator dostrzegał „ducha anarchii", którego najnowszym wcieleniem miało być liberum conspiro, anarchizujące nie władze zaborcze, lecz własny naród ${ }^{28}$. W niejednym jednak poglądy Szujskiego okazywały się zbieżne z Diagnozq Wolskiego: obaj autorzy rozumieli demokrację jako "rozbudzony do obywatelstwa duch powszechny" ${ }^{29}$, za zgubne uważali dzielenie patriotyzmu narodu na dwa nurty ${ }^{30}$, a przyczynę upadku Polski zgodnie dostrzegali w braku uwłaszczenia i uobywatelnienia ludu ${ }^{31}$. Stwierdzając, że demokracja w Polsce nie spełniła przypisanej jej wielkiej roli dziejowej, Szujski określał ją mianem "pseudodemokracji” i przewidywał, że będzie musiała ona przejść taką samą przemianę jaką przeszedł on sam. Demokracja miała więc w istocie dojrzeć do tego, aby stać się... „konserwatywnym zastępem”32.

Część zarzutów, które Szujski postawił demokracji (zanarchizowanie społeczeństwa, konspiracja prowadząca do walki $\mathrm{z}$ własnym narodem, naśladownictwo Zachodu, niezrozumienie ludu), stanowi zwierciadlane odbicie zarzutów Wolskiego wobec stronnictwa konserwatywnego. $Z$ kolei również wymieniane przez Szujskiego zalety kierunku konserwatywnego (postępowość jako antyteza niewoli i ciemnoty) sytuują go w pobliżu idei demokratycznych. Paradoksalnie więc Szujski w tekście O fałszywej historii bronił swego konserwatyzmu, odwołując się do... wartości demokratycznych. Nie przypadkiem może krakowski historyk nie zgadzał się z określeniem „nowej szkoły historycznej” jako „monarchicznej”33. Wydaje się więc, że opinia Wilhelma Feldmana, iż Szujski w 1867 r. „nie mógł od razu wypruć wszystkich swych nerwów postępowca" ${ }^{34}$ zachowała aktualność także dekadę później. Można odnieść wrażenie, że omawiany artykuł ukazuje Szujskiego jako rozczarowanego demokratę, który potępiając swe dawne ideały, wciąż ich broni, tym razem jednak nadając im nową nazwę - ideałów „konserwatywnych”.

Fundamentem polemiki Szujskiego był zarzut, że Wolski przejął od romantycznych historyków - Joachima Lelewela, Jędrzeja Moraczewskiego i Henryka

cz. 2: 1860-1900, Łódź 1956, s. 59-61; H.S. Michalak, Józef Szujski 1835-1883. Światopogląd i działanie, Łódź 1987, s. 238-241; M. Król, Przedmowa, w: Stańczycy. Antologia myśli społecznej i politycznej konserwatystów krakowskich, Warszawa 1985, s. 10-12.

${ }^{28} \mathrm{~J}$. Szujski, O fałszywej historii jako mistrzyni fałszywej polityki. Z powodu artykułu p. L. Wolskiego pod tytułem Diagnoza (wyd. drugie), w: Józefa Szujskiego z Ludwikiem Wolskim polemika w sprawach narodowych, Lwów 1878, s. 67-68.

29 Tamże, s. 75.

30 Tamże, s. 72-73.

31 Tamże, s. 57.

32 Tamże, s. 74.

33 Tamże, s. 78.

${ }^{34}$ W. Feldman, Stronnictwa i programy polityczne w Galicji 1846-1906, t. 1, Kraków 1907, s. 130. 
Schmitta - błędny pogląd o wolności jako „przyrodzonym kierunku Polaków”. Ta właśnie „fałszywa historia” miała być nauczycielką „fałszywej polityki” demokratów. Nic więc dziwnego, że wymieniony wśród rzeczników „fałszywej historii” Henryk Schmitt poczuł się wywołany do odpowiedzi i udzielił jej, podejmując polemikę z koryfeuszem stronnictwa krakowskiego.

Henryk Schmitt należał do grona demokratów lwowskich, był uczestnikiem galicyjskich konspiracji, rewolucji $1846 \mathrm{r}$. oraz powstania styczniowego 1863-1864. Dwukrotnie, w $1841^{35}$ i 1846 r., był skazany przez sąd austriacki na karę śmierci za zdradę stanu. W 1841 r. uniknął egzekucji dzięki aktowi łaski cesarskiej (wyszedł $\mathrm{z}$ więzienia w $1845 \mathrm{r}$.), w $1846 \mathrm{r}$. zaś dzięki zamianie wyroku na 20 lat więzienia ${ }^{36}$. W 1848 r. wolność przywróciła mu amnestia dla więźniów politycznych. Aresztowany w $1846 \mathrm{r}$. za udział w wyprawie na Narajów w grupie powstańców pod dowództwem Teofila Wiśniowskiego, w odróżnieniu od pozostałych osadzonych wykazał się w śledztwie odwagą obywatelską i podobnie jak Wiśniowski przyznał się do walki o niepodległość kraju. Nie wydając nikogo, oświadczył też, że nie uznaje rządu austriackiego za władzę legalną, nie może być więc uważany za poddanego austriackiego i z tego względu nie jest zbrodniarzem stanu, tylko jeńcem wojennym $^{37}$. Uznawany za najwierniejszego kontynuatora poglądów Joachima Lelewela na historię Polski ${ }^{38}$, był autorem monografii Dzieje panowania Stanisława Augusta Poniatowskiego (t. 1-3, Lwów 1868-1880). We Lwowie związał się z działaczami niepodległościowymi, m.in. z Janem Dobrzańskim, wszedł w skład redakcji demokratycznego „Dziennika Literackiego”, w którym zamieszczał swoje pierwsze szkice historyczne, a także nowatorskie przemyślenia dotyczące polskiego piśmiennictwa historycznego ${ }^{39}$. W czasie powstania styczniowego działał w lwowskim Komitecie Bratniej Pomocy, organizacji przeciwstawnej „białym”. W maju 1864 r.

${ }^{35}$ Schmitt od 1837 r. działał w tajnej organizacji patriotycznej Wolnych Haliczan, a od 1839 r. był członkiem organizacji Synowie Ojczyzny, przygotowującej powstanie z udziałem włościan.

${ }^{36}$ Wyrok śmierci na Schmitta zapadł w sądzie karnym we Lwowie 10 IX 1846 r., następnie 11 VII 1847 r. w Wiedniu zatwierdzono wyroki w sprawie narajowskiej. Schmittowi zmieniono karę śmierci na 20 lat więzienia, wyrok przez powieszenie wykonano na Teofilu Wiśniowskim i Józefie Kapuścińskim 31 VII 1847 r. na Górze Straceń we Lwowie.

${ }^{37}$ W. Górczyński, Henryk Schmitt (1817-1883), w: Złota ksiegga historiografii lwowskiej XIX i XX w., Rzeszów 2007, s. 85-86; S. Kieniewicz, Wstęp, w: Henryka Schmitta listy do żony (1845-1880), oprac. S. Kieniewicz, Wrocław 1961, s. VII; List Henryka Schmitta do Leokadii Mitraszewskiej, 10-13 XII 1846 r., w: tamże, s. 14.

38 A. Wierzbicki, Historiografia polska doby romantyzmu..., s. 346.

${ }^{39}$ H. Schmitt, Jędrzej Zamojski i jego projekt do Księgi Ustaw, „Dziennik Literacki” 1859, nr 1-15; tenże, Pogląd na żywot i pisma księdza Hugona Kołłątaja, „Dziennik Literacki” 1859, nr 73-104; tenże, Zadanie dziejopisarstwa, „Dziennik Literacki” 1853, nr 6; tenże, Pogląd na rozwój, ducha i kierunek dziejopisarstwa polskiego w wieku XIX, „Dziennik Literacki” 1859, nr 44-56, 58-66. Grabski zwrócił uwagę, że w tym ostatnim szkicu Schmitt wprowadził pojęcie „szkoły historycznej” i już u Adama Naruszewicza dostrzegał poglądy monarchiczne; zob. A.F. Grabski, Orientacje polskiej myśli historycznej. Studia i rozważania, Warszawa 1972, s. 12. 
został skazany przez sąd karny we Lwowie na rok więzienia za artykuł opublikowany rok wcześniej w „Tygodniku. Dodatku do Gońca” (1863, nr 9) Kilka uwag co do sposobu prowadzenia dziś wojny w Polsce, w którym omawiał sposoby prowadzenia wojny partyzanckiej. Doświadczony w kontaktach z austriacką władzą sądowniczą, nie czekał na wynik apelacji od wyroku i w lipcu 1864 r. udał się przez Pragę i Drezno do Paryża, skąd doczekawszy amnestii, wrócił do Lwowa jesienią $1865 \mathrm{r}^{40}$

O ile artykuł Szujskiego O fałszywej historii jest tekstem w historiografii dobrze znanym, to polemiczny wobec niego artykuł Henryka Schmitta Kilka mysli na czasie w sprawach publicznych (1877) w powojennej historiografii nie był omawiany. Nie wspomniał o nim Stefan Kieniewicz w biogramie Schmitta w Polskim słowniku biograficznym $m^{41}$ ani we wstępie do edycji jego listów do żony ${ }^{42}$. Kieniewicz zwrócił natomiast uwagę, że Schmitt występował w tekstach publicystycznych przeciwko konserwatystom krakowskim już w czasie pobytu na emigracji w Paryżu ${ }^{43}$. Poglądy Schmitta na dzieje Polski nie są białą kartą historii historiografii ${ }^{44}$, a swego czasu Andrzej Feliks Grabski zwrócił uwagę, że Schmitt jeszcze przed powstaniem

40 S. Kieniewicz, Henryk Leonard Schmitt (1817-1883), w: Polski słownik biograficzny, t. 35, Wrocław-Warszawa-Kraków 1994, s. 560-561.

${ }^{41}$ Tamże, s. 559-563.

${ }^{42}$ Henryka Schmitta listy do żony...

${ }^{43}$ S. Kieniewicz, Henryk Leonard Schmitt..., s. 562. Wieloletnią krytykę historycznej szkoły krakowskiej i polityki środowiska konserwatywnego rozpoczął Schmitt wydanymi w drukarni „Ojczyzny” w Bendlikonie Uwagami wywołanymi przez broszurę pod napisem: Kilka słów z powodu odezwy ks. Adama Sapiehy (1864), w których piętnował spóźnionych krytyków decyzji o wybuchu powstania i bronił insurekcji jako postępowego ruchu, który doprowadził do uwłaszczenia. Polemikę z Szujskim zainicjował z kolei broszurą pt. Polska w rzeczywistości dziejowej a Polska przedstawiona w dziejach Józefa Szujskiego i W. Koronowicza (Bendlikon 1865), w której poddał krytyce pierwszą syntezę krakowskiego historyka. Już wówczas zarzucał mu niezrozumienie polskiego charakteru narodowego, które prowadziło do błędnego, jego zdaniem, poglądu, że państwo polskie może istnieć jedynie opierając się na „obcych” wzorcach ustrojowych, czyli jako silna monarchia dziedziczna.

${ }^{44}$ Analizowali je W. Górczyński, Podręcznikowe zarysy dziejów Polski Henryka Schmitta, w: Wielokulturowe środowisko historyczne Lwowa XIX i XX w., t. 2, red. J. Maternicki, L. Zaszkilniak, Rzeszów 2004, s. 70-84; tenże, Prace monograficzne Henryka Schmitta, w: Wielokulturowe środowisko historyczne Lwowa XIX i XX w., t. 4, red. J. Maternicki, L. Zaszkilniak, Rzeszów 2006, s. 122-145; tenże, Henryk Schmitt..., s. 85-86; D. Malczewska-Pawelec, Śląsk w pracach historyków lwowskich Ignacego Lubicz Czerwińskiego i Henryka Schmitta, w: Wielokulturowe środowisko historyczne Lwowa w XIX i XX w., t. 1, red. J. Maternicki, Rzeszów 2004, s. 178-194; J. Maternicki, Historyk w stużbie „sprawy ojczystej”. Kilka uwag o poglądach Henryka Schmitta, „Śląski Kwartalnik Historyczny Sobótka" 64, 2009, nr 2-3, s. 185-191; tenże, Historia i życie narodu..., s. 89-96; P. Sierżęga Litwa i jej związek $z$ Polska w piśmiennictwie historycznym Henryka Schmitta, w: Wielokulturowe środowisko historyczne Lwowa XIX $i$ XX w., t. 3, red. J. Maternicki, L. Zaszkilniak, Rzeszów 2005, s. 138-152; A. Wierzbicki, Spory o polska duszę. Z zagadnień charakterologii narodowej w historiografii polskiej XIX i XX wieku, Warszawa 1993 (wyd. 2: 2010); tenże, Historiografia polska doby romantyzmu..., s. 346-355. 
„nowej szkoły historycznej” „ze szczególną pasją tropił [...] narodziny w polskiej myśli historycznej poglądu, który z biegiem lat nazwany zostanie pesymistyczną koncepcją dziejów narodowych"45. Jednak polemika Schmitta ze szkołą krakowską do dzisiaj nie stała się przedmiotem szerszego zainteresowania badaczy ${ }^{46}$.

Podobnie jak Wolski, również Schmitt wystąpił z krytyką polityki stańczyków wobec kryzysu wschodniego wywołanego przez antytureckie powstania w Bośni i Hercegowinie oraz Bułgarii. Napięcia międzynarodowe powstałe wskutek tych wydarzeń budzily wśród Polaków nadzieje na odrodzenie sprawy polskiej, zwłaszcza w związku z ideą utworzenia legionów polskich w Turcji. Koncepcja ta budziła kontrowersje, a Schmitta zastanawiała jej zdecydowana krytyka ze strony stronnictwa krakowskiego. Biorąc pod uwagę teoretyczny charakter sporu (powstanie legionów nie zależało od Polaków), a także fakt, że prowadził on do ostrych podziałów, Schmitt uważał reakcję stańczyków za przesadną i domyślał się, że przedmiot owego sporu był inny niż deklarowany. Odnosząc się jednak do polityki konserwatystów krakowskich wobec kryzysu wschodniego, argumentował, że przypomnienie w takiej chwili hasła niepodległości Polski najlepiej dowodziłoby politycznej żywotności narodu polskiego ${ }^{47}$. Zadaniem polskich przedstawicieli było więc wykazać rządowi Austro-Węgier, że istnieje związek między kwestią

${ }^{45}$ A.F. Grabski, dz. cyt., s. 12. Grabski porównał Henryka Schmitta z przedstawicielem warszawskiej szkoły pozytywistycznej Władysławem Smoleńskim, który w 1886 r. opublikował pracę pt. Szkoły historyczne w Polsce. Główne kierunki pogląów na przyszłość, krytykującą założenia szkoły krakowskiej. Grabski podkreślił, że Schmitt był pierwszym historykiem, który (przed Smoleńskim) wiązał „kierunki z nurtującymi je prądami ideologicznymi, obozami politycznymi”; tamże, s. 18.

${ }^{46}$ Dziewiętnastowieczny biograf Schmitta, Józef Białynia Chołodecki (Walenty Ćwik), datował początek jego sporu z Szujskim od czasu wydania w 1866 r. pierwszych tomów pracy Schmitta Dzieje Polski XVIII i XIX wieku, osnowane przeważnie na niewydanych dotąd źródłach. Kolejnym etapem polemiki Schmitta ze stronnictwem krakowskim miał być jego Rozbiór krytyczny pomystów historiozoficznych i odkryć dziejowych pana Antoniego Walewskiego, członka czynnego krakowskiej Akademii umiejętności (1875), a ostatnim Rozbiór dzieła p.t. Dzieje Polski w zarysie przez Michała Bobrzyńskiego (1882); zob. W. Ćwik [J. Białynia Chołodecki], Henryk Schmitt. Życiorys spisany na podstawie dokumentów i korespondencji, Lwów 1888, s. 165. O polemice Schmitta ze stańczykami wspomniał także Tadeusz Kupczyński; zob. tenże, Henryk Schmitt, w: Wiek XIX. Sto lat myśli polskiej: życiorysy, streszczenia, wyjątki, t. 9: Wykaz życiorysów i wypisów, red. B. Chlebowski, Warszawa 1924, s. 324-337. Autor przedwojennej biografii Schmitta, poruszając temat publicystycznego sporu Schmitta ze szkołą krakowską, opisał Kilka myśli na czasie w sprawach publicznych, w tym także zawartą w artykule krytykę polityki austriackiej wobec szkolnictwa w Galicji; zob. A. Artymiak, Lwowianin Henryk Schmitt (Spiskowiec, powstaniec, bibliotekarz, publicysta, historyk, organizator szkolnictwa), Jędrzejów 1939, s. 119-120. Po wojnie problem stosunku Schmitta do koncepcji „nowej szkoły historycznej” był poruszany przez badaczy zajmujących się percepcją Dziejów Polski w zarysie Michała Bobrzyńskiego; zob. S. Kieniewicz, Tło historyczne „Dziejów Polski” Bobrzyńskiego, „Przegląd Historyczny” 37, 1948, s. 343-356; B. Krzemieńska-Surowiecka, Polemika wokół „Dziejów Polski w zarysie” Michała Bobrzyńskiego (w latach 1879-1890), „Zeszyty Naukowe Uniwersytetu Łódzkiego. Nauki Humanistyczno-Społeczne" 1956, Seria I, z. 4, s. 107-130.

${ }^{47}$ H. Schmitt, Kilka myśli na czasie w sprawach publicznych, Lwów 1877, s. 42-43. 
wschodnią a sprawą polską oraz przekonać go, że rozwiązanie tej ostatniej leżało $\mathrm{w}$ interesie monarchii habsburskiej. Właśnie utrzymywanie status quo stanowiło przyczynę zaburzeń w tej części Europy ${ }^{48}$. Zachowanie milczenia w tej sytuacji było natomiast przesadną ostrożnością, a nawet świadectwem braku odwagi cywilnej. Schmitt dowodził także, że przyjęta przez konserwatystów strategia milczenia przyniosła skutek odwrotny do zamierzonego. Doprowadziła bowiem do tym głośniejszego manifestowania dążeń narodowych, a także zmniejszyła zaufanie Polaków do własnej reprezentacji w Wiedniu. Nie przekonała wreszcie żadnego z państw zaborczych o rezygnacji Polaków z niepodległości ani nie powstrzymała Rosji i Prus przed kontynuacją antypolskiej polityki. A przecież zabranie przez Polaków głosu w sprawie wschodniej nie oznaczało nawoływania do rewolucji, lecz upomnienie się o należne im prawa i gest sprzeciwu wobec prześladowań. Nie oznaczało także zaniechania pracy organicznej, która skądinąd budziła nieuzasadnione obawy stańczyków ${ }^{49}$. Zdaniem Schmitta właśnie takie intencje przyświecały wystąpieniu Wolskiego. W jego Diagnozie nie dostrzegał wezwania do kolejnego zrywu narodowego, lecz jedynie do pracy organicznej, której „celem wyższym” miała być Polska. Solidaryzując się z postulatem Wolskiego, by pracy organicznej nadać charakter narodowy (tzn. zgodny $z$ dążeniem narodu i stawiający sobie za cel odzyskanie wolności) ${ }^{50}$, Schmitt przestrzegał przed zawężaniem horyzontu działań organicznych. Sprowadzanie ich do prac obliczonych jedynie na korzyść materialną bez „wyższego celu narodowego" nie mogło porwać społeczeństwa i groziło zobojętnieniem na sprawy publiczne. Warunkiem powodzenia tak rozumianej pracy organicznej była ponadzaborowa solidarność całego narodu - wszelkie podziały służyły jedynie państwom zaborczym, dążącym do rozbicia i zniszczenia polskości ${ }^{51}$.

Podważając podstawę określania demokratów mianem „anarchistów”, Schmitt ironizował zarazem, że nazywając w ten sposób swoich przeciwników, Szujski uzurpował dla swego stronnictwa pozycję (moralnego) „rządu”: „W jaki sposób rząd ten powstał, czy prawem dziedzictwa, czy na podstawie wyborów i powszechnego lub częściowego głosowania, czy wreszcie wskutek przywłaszczycielstwa, mniejsza o to, dość że jest, a co więcej, że zdaniem Szujskiego nie wolno go nazywać jak inne porozbiorowe "samozwańczym «, lecz należy mu się miano prawowitego a jako takiemu posłuszeństwo bezwarunkowe. Kto zaś śmie przeciw niemu wystąpić, lub

48 Tamże, s. 90.

49 Schmitt miał na myśli przygotowania do Rolniczo-Przemysłowej Wystawy Krajowej, organizowanej we Lwowie jesienią 1877 r., przeciwko której wystąpiło stronnictwo krakowskie. Niechęć ta, zdaniem Schmitta, wynikała z wyobrażenia wystawy jako groźnej manifestacji politycznej, podobnej do organizowania dywersji i legionów polskich. Ironicznie uznawał więc, że tego rodzaju „zmory” wywołały u Szujskiego „formalne halucynacje”, z którymi podjął on niepotrzebną walkę; tamże, s. 93.

50 Tamże, s. 73.

51 Tamże, s. 74-78. 
jego woli się sprzeciwić, albo innego być zdania, jest według Szujskiego anarchistą, samozwańcem i buntownikiem" 52 .

Zdaniem Schmitta prawomocność mandatu stańczyków do sprawowania owego „rządu moralnego” była wielce problematyczna. Sam Szujski podkreślał wprawdzie „rozum”, „chłodne usposobienie” i zasługi swych politycznych przyjaciól, ale przymioty te powinny przecież podlegać ocenie postronnych, a nie samych zainteresowanych. Zwolennicy „rządu moralnego” mogliby ewentualnie powołać się na akt wyboru posłów galicyjskich i pruskich, jednak brak wyborów w zaborze rosyjskim podważał prawo owego „rządu” do narzucania swych zasad mieszkańcom Królestwa i Ziem Zabranych ${ }^{53}$. „Z jakiegokolwiek zatem stanowiska zechcemy rozważać to pytanie, okaże się zawsze, że rząd moralny p. Szujskiego jest bez mandatu, i nie może zwać się prawowitym, z czego znów wypływa, że chcąc działać jako rząd, działać będzie jako rząd »samozwańczy«, a jego dążenia i działania $w$ sprawie odrodzenia narodu, jeśli są sprzeczne $\mathrm{z}$ zamiarami trzech rządów zaborczych, nie życzących sobie takiego odrodzenia, będą miały na sobie najwyraźniejsze piętno okrzyczanego przezeń »liberum conspiro «"54.

Uchylając zarzut „anarchizowania”, Schmitt odrzucał także oskarżenia o liberum conspiro. Jego zdaniem historycy dawnej szkoły nie wzywali do powstań, nie różnili się więc pod tym względem od historyków szkoły krakowskiej. Przypominając tym ostatnim o inicjatywach Hugona Kołłątaja i działalności warszawskiego Towarzystwa Przyjaciół Nauk, dowodził, że program pracy organicznej nie jest ich wynalazkiem ${ }^{55}$. Dopiero wskutek braku możliwości pracy jawnej Polacy podjęli potajemne działania nad odrodzeniem. Przyczyną pracy spiskowej i tajnych sprzysiężeń była więc miłość ojczyzny i wzmocniona przez represje chęć odzyskania niepodległości, a nie rzekome anarchiczne usposobienie Polaków. Krakowski „rząd moralny”, złożony przecież z ludzi „chłodnych” i kierujących się rozumem, nawet w autonomicznej Galicji nie mógł jawnie prowadzić prac organicznych. Nie tylko więc z powodu „uzurpacji” prerogatyw „rządu moralnego”, ale również wskutek sytuacji politycznej własnego narodu stańczycy mieli być skazani na działanie w ramach wyklinanego liberum conspiro. Skądinąd Schmitt daleki był od potępiania tego, co Szujski określił mianem „fałszywej polityki”, a poniesionych wskutek jej uprawiania ofiar nie uważał za daremne. Miały one zahartować „ducha narodu” i sprzyjać asymilacji z narodem polskim ludności napływowej. Stanowiło to, zdaniem lwowskiego historyka, dowód na siłę i żywotność narodu, dzięki którym ostatecznie rząd austriacki przyznał Polakom swobody w Galicji. W sformułowaniu liberum conspiro Schmitt dostrzegał zrównanie walczących o niepodległość powstańców styczniowych ze zdrajcami ojczyzny z czasów I Rzeczypospolitej,

52 Tamże, s. 46.

53 Tamże, s. 67-68.

54 Tamże, s. 68.

55 Tamże, s. 69-70. 
a także dążenie do zerwania z polską tradycją wolnościową. Nie bez wpływu osobistych doświadczeń zwracał też uwagę, że współcześnie służy ono konserwatystom do odsuwania patriotów od stanowisk i udziału w życiu publicznym ${ }^{56}$.

Rozbiór eseju Szujskiego prowadził więc Schmitta do wniosku, że krakowski historyk polemizował z poglądami, których Wolski w Diagnozie nie głosił. Jego zdaniem koryfeusz stańczyków wyminął istotę argumentacji swego przeciwnika, bezzasadnie przypisując mu dążenie do rewolucji i anarchii ${ }^{57}$. Jeśli jednak nieprawdą było, że Wolski uprawiał „fałszywą politykę”, to nie miał również podstaw zarzut posługiwania się „fałszywą historią”. Właśnie poglądy historyczne Szujskiego wywołały zasadniczą polemikę Schmitta. W swojej wypowiedzi lwowski historyk zmierzał do wniosku, że oskarżenia Szujskiego należałoby odwrócić i skierować w stronę ich autora. W tym celu Schmitt podjął się obrony lelewelowskiej tradycji historiograficznej.

Jak już wiemy, Szujski w swym eseju zaliczył Schmitta do szacownego skądinąd grona twórców „fałszywej historii”, to znaczy historii pisanej tendencyjnie i bez dążenia do prawdy. Nie po to, rzecz jasna, Schmitt sięgał po pióro, by opinii tej przyklasnąć. Odrzucając oskarżenia Szujskiego, wzywał go, aby dowiódł, w którym miejscu historiografia starej szkoły miała charakter doktrynerski lub służyła za środek do „jakichś ubocznych a społeczeństwu szkodliwych celów?"58. Zaprzeczał, by Lelewel, Moraczewski czy on sam dopasowywali fakty do założonych z góry doktryn czy teorii, zbyt łagodne lub zbyt surowe osądy owych historyków składał zaś na karb pomyłek lub czcigodnej pietas filialis ${ }^{59}$. Sięgając po raz kolejny po retorsio argumenti, Schmitt odwracał zarzut tendencyjności w stronę szkoły krakowskiej. Przekonywał, że to właśnie należący do niej historycy stawiali sobie za cel nie osiągnięcie prawdy historycznej, lecz „uzasadnienie doktryny, że królowie tylko polscy i ich zwolennicy pragnęli dobra, szczęścia, potęgi i świetności ojczyzny, a ogół narodu czyli szlachty nie dbał o to wszystko, udaremniał najlepsze i najzbawienniejsze zamiary ich i usiłowania dążące do jej ocalenia, i tym dowiódł rażącego braku miłości ku niej”o0.

Należy jednak w tym miejscu zaznaczyć, że pojęcia „prawdy historycznej” Schmitt używał w specyficznym znaczeniu. Zgodnie z romantycznym przekonaniem o narodach jako indywidualnych bytach rozwijających się na swój niepowtarzalny sposób, Schmitt oczekiwał od badań historycznych odkrycia „idei narodowej”,

${ }^{56}$ W 1869 r. Schmitt musiał uznać wyższość Szujskiego w staraniach o nowo utworzoną Katedrę Historii Polski na Uniwersytecie Jagiellońskim. Innym przykładem niechętnego stosunku stronnictwa krakowskiego do środowiska demokratów był przypadek Józefa Ignacego Kraszewskiego, którego kandydatura została zablokowana przy staraniach o kierownictwo Katedry Historii Literatury Polskiej na UJ, objętej w 1871 r. przez Stanisława Tarnowskiego.

57 H. Schmitt, Kilka myśli na czasie..., s. 45.

58 Tamże, s. 48.

59 Tamże, s. 51.

60 Tamże, s. 65-66. 
tkwiącej u zarania dziejów i niezmiennej w całym ich przebiegu, która określała „indywidualne cechy narodu" i swoistą drogę jego rozwoju ${ }^{61}$. Właśnie dotarcie do owej „idei narodowej” stanowiło dla Schmitta „prawdę historyczną," skądinąd już dawno ustaloną, skoro lwowski historyk jako wierny uczeń Lelewela za polską „ideę" skłonny był uważać wolność i równość. Jeśli „prawda historyczna” polegała na odkrywaniu ,idei narodowej”, to zadaniem historii było budowanie narodowej tożsamości. Nietrudno zauważyć, że założenia te musiały usztywniać stanowisko Schmitta. Nic więc dziwnego, że w krytyce tradycyjnego (lelewelowskiego) poglądu na narodową przeszłość dostrzegał zagrożenie dla samego bytu narodowego, co tłumaczy jego pełne pasji, retoryczne pytania, czy historycy starej szkoły mieli wyprzeć się swoich przodków, uznając ich za „zgraję najnikczemniejszych anarchistów, głupców, niedołęgów, a nawet zbrodniarzy"62, a badając dzieje ojczyste, powinni byli odkryć, że „cała przeszłość Polski diabła warta, i że cały naród polski z wyjątkiem garsteczki zwolenników nowszej szkoły historycznej był i jest czymś potwornym i pokurczowym w znaczeniu społecznym i politycznym, któremu należy zatem śpiewać na wszystkie możliwe tony, że powinien przekształcić swą istotę, przestać być sobą i stać się czymś zupełnie innym, a więc przenarodowić się całkowicie?"63.

Z punktu widzenia epigona romantycznej szkoły historycznej, jakim niewątpliwie był Schmitt, historia krytyczna w wydaniu krakowskim (czyli badanie dziejów w celu „zdobycia mniemanej prawdy” bez „natchnienia wyższego i miłości”) była w warunkach zaborów „zabawką uczoną”, potencjalnie szkodliwą dla sprawy narodowej ${ }^{64}$. Szkodliwą nie tylko dlatego, że obraz dziejów Polski złożony z win i klęsk Polaków raczej wtrącałby ich $\mathrm{w}$ apatię (jak przypuszczał Schmitt), niż wyzwalał $\mathrm{z}$ wad (jak spodziewał się Szujski). Ale również, a może nawet przede wszystkim dlatego, że byłby to obraz, w którym indywidualne cechy narodu polskiego (wolność) zostałyby przedstawione jako jego wady („anarchia”). Jeśli bowiem każdy naród miał rozwijać się w sposób odrębny dzięki swoim indywidualnym cechom, to pozbawienie go tych cech byłoby jego prawdziwym końcem, a nie odrodzeniem duchowym, którego oczekiwał Szujski ${ }^{65}$.

${ }^{61}$ A. Wierzbicki, Wschód - Zachód w koncepcjach dziejów Polski..., s. 141-142. Por. pojęcie prawdy historycznej w szkole krakowskiej: S. Filipowicz, Ujarzmienie rozumu politycznego. Polityczne horyzonty krakowskiej szkoly historycznej, Warszawa 1984, s. 87-89.

${ }^{62}$ H. Schmitt, Kilka myśli na czasie..., s. 49.

63 Tamże.

${ }^{64}$ Nie tylko lwowscy demokraci zareagowali w ten sposób na tezy szkoły krakowskiej. Jak zauważył S. Filipowicz, dz. cyt., s. 87, publiczność niechętnie godziła się na uznanie prawdy naukowej za suwerena, „który może liczyć na bezwzględne, niezależne od okoliczności, uznanie swych praw".

${ }^{65}$ Był to oczywiście konflikt monolinearnego i polilinearnego modelu rozwoju historycznego, jaki dzielił historyków szkoły lelewelowskiej i szkoły krakowskiej; zob. A. Wierzbicki, Wschód - Zachód w koncepcjach dziejów Polski..., s. 16-17. 
Autor eseju O fałszywej historii rzeczywiście zakwestionował pogląd, jakoby wolność stanowiła „pierwiastek składowy indywidualizmu narodu polskiego”. Jego zdaniem w Polsce od czasów Bolesława Chrobrego miało panować prawo książęce i patriarchalna dynastyczność, a nie dążenie do wolności. Ta ostatnia miała się w Polsce pojawić dopiero wraz z nastaniem Kościoła, immunitetem kościelnym, który stanowił wyłom w prawie książęcym, oraz z prowadzoną przez Kościół akcją osadnictwa na prawie niemieckim. Pośrednio miała tego dowodzić walka wszystkich stanów i wyznań przeciwko wolności Kościoła. Królowie (Szujski wymieniał Kazimierza Wielkiego i Kazimierza Jagiellończyka), różnowiercy, a także szesnastowieczna szlachta występowali przeciwko instytucji Kościoła, domagając się wzmocnienia władzy królewskiej. Dopiero w okresie bezkrólewia po śmierci Zygmunta Augusta szlachta sięgnęła po wolność, jednak w ujęciu Szujskiego był to "nie duch w naród tchniony, [lecz] to "Dejaniry paląca koszula « rzucona na społeczeństwo", która doprowadziła do upadku państwa. Zdaniem Szujskiego błędne rozumienie wolności w dziejach Polski było dziełem dawniejszej historiografii i w swoim czasie niezmiernie popularnych Śpiewów historycznych Juliana Ursyna Niemcewicza ${ }^{66}$. Biorąc w obronę „optymistyczne” koncepcje dawniejszej historiografii, Schmitt podkreślał przede wszystkim, że bez poetyckich emanacji wolnościowej wizji dziejów Polski aktualny spór byłby bezprzedmiotowy, bo dawno zniknęliby użytkownicy języka polskiego. Stwierdzał więc, że Śpiewy historyczne Niemcewicza bardziej przysłużyły się sprawie narodowej niż odkrycia „nowej szkoły historycznej”. Podobnie jak Wolski, Schmitt podawał zresztą w wątpliwość zarówno nowoczesność tej szkoły (kwerendy archiwalne, krytyka źródeł i monografie miały być znane już przed jej powstaniem), jak i sens owej nowoczesności. Zgodnie ze swoją koncepcją "prawdy historycznej” uważał bowiem, że monografie naukowe mogą jedynie pomóc w całościowym zrozumieniu dziejów ${ }^{67}$.

Dlatego podkreślał, że historyków starej szkoły mniej interesowało porównanie rządów Bolesława Chrobrego z rządami Włodzimierza II kijowskiego niż poznanie ,indywidualnych cech materiału narodowego" z czasów powstania państwa polskiego oraz owych cech trwałość. Dowodził, że dotarcie do nich było możliwe dzięki dokonanemu przez biskupa Ottona z Bambergu (1060-1139) opisowi obyczajów Słowian pomorskich, wśród których miały zachować się dawne zwyczaje i zasady polityczne, wspólne jakoby wszystkim Słowianom. Skoro zaś w świetle tego źródła wolność okazywała się najważniejszym składnikiem życia społecznego Słowian pomorskich, to historycy dawnej szkoły uznali, że stanowiła ona także podstawę ustroju społecznego ludności zamieszkującej tereny Polski właściwej ${ }^{68}$. W świetle tego wywodu Schmitta uznanie wolności za polską ,ideę" nie było

${ }^{66}$ J. Szujski, O fałszywej historii jako mistrzyni fałszywej polityki. Z powodu artykułu p. L. Wolskiego pod tytułem Diagnoza..., s. 59.

${ }_{67}$ H. Schmitt, Kilka myśli na czasie..., s. 52-53.

68 Tamże, s. 54-55. 
wymysłem historyków, „którzy więcej marzą, niż wiedzą” (jak twierdził Szujski), lecz uzasadnioną źródłowo tezą naukową.

Tym samym lwowski historyk odrzucał także twierdzenie Szujskiego, że wolność rozwinęła się w Polsce dopiero dzięki instytucji Kościoła. Schmitt podkreślał, że Kościół oznaczał zarówno chrześcijaństwo, jak i hierarchię. O ile jednak idę wolności istotnie można wiązać $\mathrm{z}$ chrześcijaństwem, to Kościół jako instytucja bronił raczej swoich przywilejów stanowych niż wolności narodu. Wolność nadana przez Kościół była w istocie jedynie przywilejem ekonomicznym, a nie wolnością rozumianą jako udział w polityce.

Z kolei wolność stanu rycerskiego lwowski historyk dostrzegał już w przebiegu konfliktów możnowładztwa z Bolesławem Śmiałym i palatynem Sieciechem, od tych wydarzeń też datował początek wprowadzania wolności do ustroju społeczno-politycznego Polski ${ }^{69}$. Dalszy jej rozwój miał przypaść na okres rozbicia dzielnicowego, gdy walczący ze sobą książęta uszczuplali swą władzę, płacąc przywilejami za posłuszeństwo rycerstwa. W tym czasie zwiększyła się pozycja rycerstwa i możnych, wprawdzie także Kościoła, ale Schmitt podkreślał, że to nie Kościół przyczynił się do uzyskania wolności przez rycerstwo. Podnoszonemu przez rycerstwo żądaniu równości praw obywatelskich mieli sprzeciwiać się pozostałe stany - panowie i właśnie duchowieństwo. Pomimo oporu, stan szlachecki stopniowo jednak zwiększał swoje wpływy za czasów Władysława Łokietka i Kazimierza Wielkiego, by w okresie panowania Kazimierza Jagiellończyka uzyskać prawo zwoływania sejmów ${ }^{70}$.

Przyznając, że system demokracji szlacheckiej miał wiele niedoskonałości, Schmitt nie godził się na potępianie całej przeszłości. Za jedyny błąd dawnego rycerstwa uznawał ograniczenie narodu do własnego stanu i odsunięcie od praw i wolności reszty mieszkańców Królestwa ${ }^{71}$. W owych prawach i wolnościach szlacheckich (łącznie $z$ ich ograniczeniem do jednego stanu) Schmitt dostrzegał kontynuację „staropolskich” instytucji czasów przedpiastowskich, dostosowanych do zmieniających się stosunków i położenia państwa. Nie ukrywał, że system ten miał wady, z których największym był brak skutecznego zabezpieczenia kraju przed najazdami sąsiadów ${ }^{72}$. Mianem „doktrynerstwa” określał jednak opinię Szujskiego, że demokracja szlachecka wykluczała stworzenie dobrych zasad rządzenia i z samej swej natury była niereformowalna. Ostatecznie w tym samym systemie rządów Stefan Batory zjednał sobie naród, nie potrafili zaś tego Wazowie, których panowanie Schmitt charakteryzował następująco: „przybyli do Polski z wyobrażeniem władztwa $\mathrm{z}$ bożej łaski, zaczęli zmawiać się z obcymi na szkodę Polski, poświęcali jej dobro swym interesom dynastycznym, pomagali starannie jezuitom w gaszeniu

69 Tamże, s. 56-57.

70 Tamże, s. 58.

71 Tamże, s. 59.

72 Tamże. 
wszelkiego światła w narodzie a na dobitek wplątali R[zecz]p[ospoli]tę w celach dynastycznych w najcięższe wojny, przepadła ufność w narodzie, a tem samem i w owej formie rządu rozwinęły się wszystkie wady, $z$ których następnie wytworzył się zupełny bezrząd"73. Dowodząc w ten sposób, że zasady rządzenia zależą od wpływu czynnika ludzkiego, lwowski historyk obarczał zarazem tak wychwalany przez Szujskiego „czynnik monarchiczny” odpowiedzialnością za przyszły upadek Polski $^{74}$. Ponownie odwracając argumentację swego przeciwnika, Schmitt przekonywał więc, że polski „bezrząd” nie pojawił się w rezultacie szlacheckiej niesforności, lecz był efektem działania polskich królów przeciwko własnemu narodowi. Ale nawet popadłszy w tak ciężkie położenie, demokracja szlachecka okazywała się zdolna do samonaprawy. Dzięki podniesieniu poziomu oświaty polska szlachta zaczęła dojrzewać do uzdrowienia ustroju państwa, czego uwieńczeniem była Konstytucja 3 maja. Szlachta była więc zdolna do wyzbycia się egoizmu stanowego, wbrew temu, co Szujski twierdził o „skamieniałej” formie rządów w Polsce.

Schmitt podkreślał, że choć również i ta ustawa rządowa nie była wolna od wad, to jednak w trudnych warunkach opozycji magnackiej i silnych wpływów zewnętrznych twórcom konstytucji udało się przeprowadzić wielkie zmiany ustrojowe, ustanawiając rząd, wojsko, zrównując mieszczan w prawach obywatelskich i znosząc liberum veto. Doniosłość Konstytucji 3 maja pozwalała Schmittowi przypuszczać, że w korzystniejszych warunkach doszłoby w ciągu kilkudziesięciu lat do całkowitej naprawy państwa ${ }^{75}$. W konkluzjach odrzucał więc tezę, że cała historia Polski składała się z samych błędów, a jej upadek był ich nieuniknionym rezultatem. $\mathrm{Na}$ tym, zdaniem Schmitta, polegała główna różnica między szkołą lelewelowską a szkołą krakowską, dla której całe dzieje Polski miały stanowić przykład ,jak być nie powinno". Rozbieżność między obiema szkołami historycznymi była więc w ujęciu Schmitta przede wszystkim różnicą podejścia „pedagogicznego". O ile dawna szkoła starała się ukazać narodową przeszłość w sposób „ogrzewający serca miłością" i „hartujący ducha”, aby pomóc narodowi przetrwać niewolę zaborów, o tyle nowa zamierzała przedstawić dzieje Polski „w całej prawdzie i grozie”, aby w ten sposób „przywieść naród do otrzeźwienia i poznania wad własnych i tym spowodować odrodzenie jego przez pozbycie się tychże"76. Schmitt był przekonany, że lepiej dostosowaną do sytuacji zaborów jest praktykowana przez lelewelistów metoda zachęty, wskazywania cnót obywatelskich jako wzoru do naśladowania ${ }^{77}$. Wątpił natomiast, czy przyjęta przez historyków krakowskich werystyczna metoda "plastycznego opisania sekcji trupa szkaradnie owrzodzonego" ${ }^{78}$ skłoni naród do

73 Tamże, s. 60.

74 Tamże.

75 Tamże, s. 61.

76 Tamże, s. 62.

77 Tamże.

78 Tamże, s. 63. 
poprawy. Posługując się porównaniem polityki Ottona von Bismarcka i Aleksandra Wielopolskiego, dowodził, że sukces odniósł nie ten polityk, który ośmieszał świętości i ideały swoich rodaków, lecz ten, który owe świętości i ideały czcił, aby wzmocnić jedność narodową ${ }^{79}$. Niepokoił się, że szkoła krakowska bezwiednie pomaga zaborcom $\mathrm{w}$ dziele rozkładu narodu polskiego.

$\mathrm{Z}$ wywodów Schmitta wyłania się ideał historii, która powinna odpowiadać na potrzeby społeczne. Lwowski historyk nie uważał jednak, by realizująca ten ideał historia była eo ipso tendencyjna. Owszem, historycy szkoły lelewelowskiej akcentowali raczej momenty dziejów narodowych budzące miłość ojczyzny, ale nie mijali się z prawdą. Historycy krakowscy nie mieli więc podstaw, by oskarżać ich o „fałszowanie historii”. Jedyną przyczynę tych oskarżeń Schmitt widział zatem w fakcie, że obraz dziejów szkoły romantycznej różnił się od wytycznych „nowej szkoły historycznej”" . Jeśli zaś symptomem "fałszywej historii” miała być „fałszywa polityka", to Schmitt wskazywał, że potępiając narodową przeszłość i głosząc lojalizm, Szujski podążał drogą wyznaczoną przez Antoniego Walewskiego, rzecznika „zbawienia” narodu polskiego w sojuszu z caratem. Nie szczędząc ironii, Schmitt zauważał, że Szujski nie był jednak konsekwentny, gdyż przewidywał przyszłe „połączenie odrodzonej Polski z odrodzoną Moskwą za pośrednictwem Austro-Węgier, pracujących nad tym niesłychanej doniosłości dziełem"81.

Jak widać, polemiczny zapał prowadził Schmitta do wyostrzenia różnic między lelewelistami a szkołą krakowską. W przeciwnym kierunku zmierzał (skądinąd wcale nieustępujący Schmittowi temperamentem) Wolski, który w kończącym dyskusję wystąpieniu powtórzył wprawdzie swoje zasadnicze tezy, częściowo wskazując dla nich nawet nowe argumenty, ale zarazem podjął próbę odnalezienia punktów wspólnych ze stanowiskiem adwersarza.

Lwowski publicysta podtrzymywał oczywiście tezę o wolnościowej naturze Polaków, wskazując zarazem na niekonsekwencje w poglądach Szujskiego na to zagadnienie. Autorowi $O$ fatszywej historii przypominał w tym celu jego własne wypowiedzi z Dziejów Polski (1862) oraz Roztrzasań i opowiadań historycznych (1876). Z zestawienia tego wynikało, że Szujski negował istnienie wolności w działaniach narodu polskiego, jednocześnie dowodząc, że dążenia do niej spowodowały upadek państwa. W polemice $\mathrm{z}$ Wolskim krakowski historyk łączył pojawienie się wolności w Polsce dopiero z XVI w., chociaż w Dziejach Polski opisał dążenia książąt do samodzielności już w okresie rozbicia dzielnicowego i uznał ówczesne wiece możnowładców za początek późniejszych rokoszów i konfederacji. Dostrzegając w tych faktach symptomy dążenia do wolności, Wolski przypisywał je „naturze" narodu polskiego. Gdyby bowiem wolność nie była częścią natury narodu,

\footnotetext{
79 Tamże, s. 74.

80 Tamże, s. 62.

81 Tamże, s. 66.
} 
to nie przetrwałaby do czasów współczesnych. Wynikało z tego również, że Polacy przestaliby być narodem, gdyby swoją walkę o wolność uznali za kłamstwo, za winę, a nie zasługę ${ }^{82}$. Potwierdzając w ten sposób swój pogląd o fundamentalnym znaczeniu tradycji dla istnienia narodu, Wolski dodatkowo wspierał go odwołaniem do koncepcji „narodów historycznych”. Gdyby Polacy odrzucili zgubną przeszłość (jak chcieli stańczycy), nie staliby się młodym narodem, lecz zaledwie jednym z narodów bez historii, których współczesna Europa nie uznaje. Tylko tradycja mogła dać narodom świadomość, siłę oporu i działania. Ponownie sięgając do „romantycznych” wypowiedzi Szujskiego, Wolski dowodził, że koryfeusz stańczyków podzielał i tę prawdę, pisząc, że choć byłoby zgubą narodu, gdyby nie szukał winy u siebie, to byłoby samobójstwem, gdyby całą przeszłość uznał za błędną i odrzucił zasady, którym był wierny i dzięki którym „wyprzedził Europę” ${ }^{\text {. }}$.

Wolski nie po to jednak ukazywał sprzeczności w poglądach Szujskiego, by oskarżać go o brak dobrej wiary i świadome fałszowanie dziejów, lecz po to, by zaapelować do „romantycznej” cząstki jego duszy, która, jak przypuszczał Wolski, poddała się frakcji politycznej zamieniającej historię w sztywną doktrynę ${ }^{84}$. Usiłując w ten sposób nakłonić dawnego kolegę do powrotu na „narodowy gościniec”, poszukiwał (podobnie jak w inicjującym dyskusję wystąpieniu) płaszczyzny porozumienia.

Oznaczała ona przede wszystkim poszukiwanie wspólnych elementów w obrazie przeszłości. Sugerując (jak widzieliśmy), że Szujski dostrzegał znaczenie wolności w polskich dziejach, Wolski przekonywał, że również w poglądzie na upadek Rzeczypospolitej krakowski historyk w istocie nie odbiega od poglądu wyrażonego w Diagnozie. W gruncie rzeczy bowiem także Szujski za przyczynę katastrofy państwa uważał szlachecki egoizm stanowy ${ }^{85}$. Przyczyna nie mogła tkwić w zasadzie wolności, skoro sam Szujski pośrednio akceptował ją, krytykując odrzucenie wolności religijnej i politycznej na rzecz nietolerancji i zamknięcia obywatelskiego na inne stany ${ }^{86}$. Zdaniem Wolskiego nie powinien był zajmować skrajnego stanowiska, lecz po prostu uznać, że każdy ustrój państwowy ma swoje wady. O ile jednak lwowski publicysta opowiadał się za naprawieniem systemu drogą "postępu i zmian” (czyli poprzez rozwijanie narodowej tradycji), to Szujski uznawał za konieczny i uzasadniony zwrot stronnictwa dworskiego przeciwko szlachcie w stronę zasady monarchicznej. Wolski uważał jednak, że ten zwrot

82 L. Wolski, Odprawa panu Szujskiemu, w: Józefa Szujskiego z Ludwikiem Wolskim polemika..., s. $87-89$.

${ }^{83}$ Tamże, s. 90-91. Przytoczona przez Wolskiego wypowiedź Szujskiego pochodziła z jego recenzji książki Siegfrieda Hüppego Verfassung der Republik Polen (Berlin 1867); zob. J. Szujski, Roztrząsania i opowiadania historyczne (pisane w latach 1866-1870), Kraków 1876, s. 194.

${ }^{84}$ L. Wolski, Odprawa panu Szujskiemu..., s. 92-93.

85 Tamże, s. 96-97.

${ }^{86}$ Tamże, s. 94-95. 
jedynie pogłębił kryzys. Skrajne stanowisko stronnictwa dworskiego wywołało przecież reakcję szlachty, która buntując się przeciwko polityce regalistów, obwarowała swoje wolności liberum veto (co i tak, zdaniem Wolskiego, było bliższe narodowej tradycji niż „obca” zasada monarchiczna). Ta krytyka skrajności politycznej stronnictwa dworskiego stanowiła przesłankę dla wniosków politycznych.

Wolski bowiem, „rewanżując” się Szujskiemu za historyczne analogie między liberum veto a liberum conspiro, porównywał przedrozbiorowych regalistów z krakowskim stronnictwem stańczyków. Obydwa ugrupowania polityczne charakteryzowały się, jego zdaniem, podobnymi cechami - były skrajne, ulegały obcym hasłom, nie rozumiały narodu i sprzeciwiały się jego tradycjom. Takie same wywoływały też reakcje w społeczeństwie - obronę tradycji i ciemnoty. Paralelność reakcji społecznych wynikała, jak mniemał Wolski, z podobnej sytuacji wyboru: jeśli bowiem regaliści stawiali naród przed dylematem absolutyzm lub „bezrząd”, to stańczycy mieli narzucać wybór między ultramontanizmem i reakcją bądź anarchią i bezwyznaniowością ${ }^{87}$. Droga obrana przez stańczyków okazywała się więc „fałszywa”. Zaślepieni obcymi ideami (ultramontanizm, monarchizm rozumiany jako absolutyzm), kwestionowali narodowe tradycje. Opierając budowę swego stronnictwa na negacji, nie zdołali zyskać szerokiego poparcia, ponieważ zwykli ludzie do pracy i działania potrzebowali uczucia miłości ojczyzny. Uzurpowali sobie jednak prawo do sprawowania „rządu moralnego”, swoich przeciwników oskarżając o anarchię i rewolucjonizm, choć nie było wśród nich prawdziwych anarchistów i rewolucjonistów, a jedynie zwolennicy niepodległości ${ }^{88}$. W ten sposób, zamiast uspokajać nastroje, raczej je podburzali i tworzyli ostre podziały polityczne, które, jak przypuszczał Wolski, będą ich jedynym dziedzictwem: „znikome są wasze triumfy, dlatego niczego nie zbudujecie i zostanie po was ten tylko ślad, żeście rozdwajali społeczeństwo, że bijąc na obóz piastujący tradycje przeszłości, nie pozwoliliście mu wyrobić się i przeistoczyć tak, jak tego wymagały czasy i stosunki" ${ }^{\prime 9}$.

W imieniu owego „obozu piastującego tradycje przeszłości” Wolski usiłował dlatego wskazać drogę pośrednią, która miałaby rozwiązywać realne problemy społeczne Galicji (kwestie rusińską i żydowską) na podstawie narodowych ideałów ${ }^{90}$. Jej podstawą miała być wspomniana już w Diagnozie praca organiczna rozumiana jako rozwijanie „wiary moralnej narodu”, czyli jego tradycji wolności i tolerancji religijnej, które usunęłyby przyczyny rozsadzających dawną Rzeczpospolitą separatyzmów religijnych i etnicznych. Wolski ubolewał, że stronnictwo krakowskie nie podjęło na tym polu współpracy $\mathrm{z}$ demokratami, uznając ich za swoich

87 Tamże, s. 98-100.

88 Tamże, s. 105-108.

89 Tamże, s. 106.

90 Tamże, s. 100, 105. 
przeciwników ${ }^{91}$. O ile jednak ten antagonizm polityczny wspierały odmienne wizje narodowej przeszłości, o tyle przekonując swego adwersarza o zbieżnościach obu wizji, Wolski szukał sposobu na zasypanie politycznych podziałów.

Punktem wyjścia polemiki lwowskich demokratów z Szujskim był spór o politykę Koła Polskiego wobec kryzysu wschodniego lat 1875-1878, który bardzo szybko przekształcił się w spór o stosunek do powstania styczniowego i tradycji insurekcyjnej w ogóle. Polemiści obu stron w ostatnim powstaniu widzieli jednak nie tylko kluczowe wydarzenie polskiej polityki, ale także rezultat całego procesu historycznego. Dlatego ich debata stała się klasycznym przykładem sporu o relacje między polityką a historią. Nietrudno dostrzec w nim pewną symetrię: nie tylko Szujski w swym kanonicznym eseju, lecz również jego oponenci przekonywali, że to przeciwnik tworzy „fałszywą historię”, która prowadzi do uprawiania „fałszywej polityki”. Z punktu widzenia krakowskiego historyka "fałszywą historią" była dokonana $\mathrm{w}$ szkole lelewelowskiej apologia wolności, a de facto anarchii, która jego zdaniem od XVI w. niszczyła polską politykę, wcielając się zrazu w zgubne liberum veto, a po upadku państwa - w nie mniej szkodliwe liberum conspiro. Nic dziwnego, że doszedłszy do takich wniosków, Szujski wzywał do zerwania $\mathrm{z}$ tą tradycją historyczną i wynikającą z niej praktyką polityczną. Apel ten wywołał jednak oburzenie demokratów, którzy widzieli w nim zagrożenie dla bytu narodowego. $\mathrm{Z}$ ich perspektywy naród istniał bowiem dopóty, dopóki pozostawał wierny swej „idei”, którą demokraci (za Lelewelem) utożsamiali właśnie z dążeniem do wolności. $Z$ kolei teraz oni uznawali więc za "fałszywą" historię Szujskiego opartą na jakoby obcej polskiemu charakterowi narodowemu zasadzie monarchizmu (a także katolicyzmu jako podstawie życia społecznego). Również ta „fałszywa historia” miała prowadzić do „fałszywej polityki”, za jaką demokraci lwowscy uważali lojalistyczny program stańczyków.

Był to więc spór tyleż naukowy, co polityczny, który miał w istocie szerokie tło ideowe, odzwierciedlał charakter i wybory życiowe polemistów. Spośród nich demokraci lwowscy pozostali wierni swoim demokratycznym poglądom, podczas gdy Szujski dokonał ideowej wolty. Była ona jednak może mniejsza, niż wydaje się na pierwszy rzut oka.

Warto zauważyć, że w omawianym sporze po obu stronach padały argumenty, które można uznać za paradoksalne. Lwowscy demokraci okazywali się zwolennikami tradycji, a ich wizja postępu organicznego, rozumianego jako dostosowywanie tradycyjnych idei do zmieniającego się czasu, przypominała koncepcje konserwatywne, skądinąd bliskie krakowskim stańczykom ${ }^{92}$. Z kolei

\footnotetext{
91 Tamże, s. 105.

92 M. Król, dz. cyt., s. 19-24.
} 
w konserwatyzmie Szujskiego odnaleźć można elementy myślenia demokratycznego (idea postępu jako antytezy niewoli i ciemnoty), a w jego gwałtownym ataku na polską „pseudodemokrację" - obronę demokracji jako takiej ${ }^{93}$. Te ambiwalencje myślenia rozczarowanego demokraty nie umknęły uwadze badaczy ${ }^{94}$. Określając Szujskiego mianem „romantyka i zarazem krytyka romantyzmu”, Henryk Stanisław Michalak zwracał uwagę, że krakowski historyk próbował łączyć duszę demokraty $\mathrm{z}$ rozumem konserwatysty i nie porzucił romantycznych ideałów, przekładając je na realizm polityczny ${ }^{95}$. Z taką samą energią, z jaką działał w obozie „czerwonych”, rozwinął działalność na polu nauki i polityki, zgodnie z opinią Henryka Schmitta, że praca organiczna nawet w autonomicznej Galicji też nosiła znamiona konspiracji. Wyczuwali to rozdarcie rozczarowanego demokraty polemiści (zwłaszcza Wolski), podejmując próbę jego „nawrócenia” na drogę, która zdawała im się „narodowym gościńcem”.

\section{Bibliografia}

\section{Źródła}

Henryka Schmitta listy do żony (1845-1880), oprac. S. Kieniewicz, Wrocław 1961

J. Klaczko, Deux chanceliers, III L'action commune, „Revue des deux Mondes” 10, 1875, s. 741-786

Mowy Ludwika Wolskiego i Ottona Hausnera dnia 4. i 5. listopada 1878 w parlamencie austriackim, wyd. 2, Lwów 1879

T. Romanowicz, Polityka stańczyków. Odpowiedź na referat prof. dra Leona Bilińskiego „O stronnictwie stańczyków", Kraków 1882

H. Schmitt, Kilka myśli na czasie w sprawach publicznych, Lwów 1877

H. Schmitt, Polska $w$ rzeczywistości dziejowej a Polska przedstawiona $w$ dziejach Józefa Szujskiego $i$ W. Koronowicza, „Pismo Zbiorowe Towarzystwa Naukowego Młodzieży Polskiej w Paryżu” 1, 1865 , z. 2-3, s. 87-118, 264-324

H. Schmitt, Uwagi wywołane przez broszurę pod napisem: Kilka słów z powodu odezwy ks. Adama Sapiehy, Bendlikon 1864

J. Szujski, O broszurze p. Pawła Popiela „List do ks. Jerzego Lubomirskiego”, Lwów 1865

J. Szujski, O fałszywej historii jako mistrzyni fałszywej polityki. Rozprawy i artykuły, wybór, oprac. i wstęp H.S. Michalak, Warszawa 1991

J. Szujski, O fatszywej historii jako mistrzyni fatszywej polityki. Z powodu artykułu p. L. Wolskiego pod tytułem Diagnoza (wyd. drugie), w: Józefa Szujskiego z Ludwikiem Wolskim polemika w sprawach narodowych, Lwów 1878, s. 55-82

S. Tarnowski, Po dziesięciu latach, „Przegląd Polski”, VII 1876

L. Wolski, Diagnoza, w: Album Muzeum Narodowego w Rapperswyllu, red. J.I. Kraszewski, Lwów 1876 , s. $274-294$

L. Wolski, Odprawa panu Szujskiemu, w: Józefa Szujskiego z Ludwikiem Wolskim polemika w sprawach narodowych, Lwów 1878, s. 83-109

${ }^{93}$ L. Wolski, Odprawa panu Szujskiemu..., s. 75-78.

${ }^{94}$ W. Feldman, dz. cyt., s. 130, 143; R.R. Ludwikowski, Główne nurty polskiej myśli politycznej 1815-1890, Warszawa 1982, s. 80-86; H.S. Michalak, dz. cyt., s. 241-242.

${ }^{95}$ H.S. Michalak, dz. cyt., s. 241-242. 


\section{Opracowania}

J. Adamus, Syntezy historyczne Szujskiego, w: Studia historyczne ku czci Stanisława Kutrzeby, t. 2, Kraków 1938, s. 1-27

A. Artymiak, Lwowianin Henryk Schmitt (Spiskowiec, powstaniec, bibliotekarz, publicysta, historyk, organizator szkolnictwa), Jędrzejów 1939

J. Buszko, Polacy w parlamencie wiedeńskim 1848-1918, Warszawa 1996

W. Ćwik [J. Białynia Chołodecki], Henryk Schmitt. Życiorys spisany na podstawie dokumentów $i$ korespondencji, Lwów 1888

W. Feldman, Stronnictwa i programy polityczne w Galicji 1846-1906, t. 1, Kraków 1907

S. Filipowicz, Ujarzmienie rozumu politycznego. Polityczne horyzonty krakowskiej szkoły historycznej, Warszawa 1984

W. Górczyński, Henryk Schmitt (1817-1883), w: Złota księga historiografii lwowskiej XIX i XX w., Rzeszów 2007, s. 81-100

W. Górczyński, Podręcznikowe zarysy dziejów Polski Henryka Schmitta, w: Wielokulturowe środowisko historyczne Lwowa XIX i XX w., t. 2, red. J. Maternicki, L. Zaszkilniak, Rzeszów 2004, s. 70-84

W. Górczyński, Prace monograficzne Henryka Schmitta, w: Wielokulturowe środowisko historyczne Lwowa XIX i XX w., t. 4, red. J. Maternicki, L. Zaszkilniak, Rzeszów 2006, s. 122-145

A.F. Grabski, Orientacje polskiej myśli historycznej. Studia i rozważania, Warszawa 1972

W. Hahn, Karol Libelt we Lwowie w roku 1869, Lwów 1907

Historia dyplomacji polskiej, t. 3, red. L. Bazylow, Warszawa 1982

S. Kieniewicz, Henryk Leonard Schmitt (1817-1883), w: Polski słownik biograficzny, t. 35, Wrocław-Warszawa-Kraków 1994, s. 559-563

S. Kieniewicz, Tło historyczne „Dziejów Polski” Bobrzyńskiego, „Przegląd Historyczny” 37, 1948, s. 343-356

M. Król, Przedmowa, w: Stańczycy. Antologia myśli społecznej i politycznej konserwatystów krakowskich, Warszawa 1985, s. 5-37

B. Krzemieńska-Surowiecka, Polemika wokót „Dziejów Polski w zarysie” Michała Bobrzyńskiego (w latach 1879-1890), „Zeszyty Naukowe Uniwersytetu Łódzkiego. Nauki Humanistyczno-Społeczne" 1956, Seria I, z. 4, s. 107-130

T. Kupczyński, Henryk Schmitt, w: Wiek XIX. Sto lat myśli polskiej: życiorysy, streszczenia, wyjątki, t. 9, red. B. Chlebowski, Warszawa 1924, s. 324-337

R.R. Ludwikowski, Główne nurty polskiej myśli politycznej 1815-1890, Warszawa 1982

J. Maciejewski, Przedburzowcy. Z problematyki przełomu między romantyzmem a pozytywizmem, Kraków 1971

D. Malczewska-Pawelec, Śląsk w pracach historyków lwowskich Ignacego Lubicz Czerwińskiego i Henryka Schmitta, w: Wielokulturowe środowisko historyczne Lwowa XIX i XX w., t. 1, red. J. Maternicki, Rzeszów 2004, s. 178-194

J. Maternicki, Historia i życie narodu. Pogląy i postawy historyków polskich XIX i XX w., Rzeszów 2009

J. Maternicki, Historyk w służbie „sprawy ojczystej”. Kilka uwag o pogladach Henryka Schmitta, „Śląski Kwartalnik Historyczny Sobótka" 64, 2009, nr 2-3, s. 185-191

H.S. Michalak, Józef Szujski 1835-1883. Światopogląd i działanie, Łódź 1987

L. Michalska-Bracha, Między pamięcia a historiografią. Lwowskie debaty o powstaniu styczniowym (1864-1939), Kielce 2011

L. Michalska-Bracha, Powstanie styczniowe w pamięci zbiorowej społeczeństwa polskiego $w$ okresie zaborów, Kielce 2003

M.H. Serejski, Historycy o historii. Od Adama Naruszewicza do Stanisława Kętrzyńskiego, t. 1: 1775-1918, Warszawa 1963 
M.H. Serejski, Zarys historii historiografii polskiej, cz. 2: 1860-1900, Łódź 1956

P. Sierżęga, Litwa i jej związek $z$ Polska w piśmiennictwie historycznym Henryka Schmitta, w: Wielokulturowe środowisko historyczne Lwowa XIX i XX w., t. 3, red. J. Maternicki, L. Zaszkilniak, Rzeszów 2005, s. 138-152

H. Wereszycki, Walka o pokój europejski 1872-1878, Warszawa 1971

A. Wierzbicki, Historiografia polska doby romantyzmu, Wrocław 1999

A. Wierzbicki, Poczet historyków polskich. Historiografia polska doby podzaborowej, Poznań 2014

A. Wierzbicki, Spory o polska duszę. Z zagadnień charakterologii narodowej w historiografii polskiej XIX $i$ XX wieku, Warszawa 1993 (wyd. 2: 2010)

A. Wierzbicki, Wokót „czarnej legendy” historiografii krakowskich konserwatystów, „Kwartalnik Historyczny" 104, 1997, nr 2, s. 63-87

A. Wierzbicki, Wschód - Zachód w koncepcjach dziejów Polski. Z dziejów polskiej myśli historycznej $w$ dobie porozbiorowej, Warszawa 1984

\section{Two views of Polish history: the polemic between Lwów democrats, Henryk Schmitt and Ludwik Wolski, and the representative of the Kraków school of history, Józef Szujski, in the seventies of the $19^{\text {th }}$ century}

The polemic between two Lwów democrats, historian Henryk Schmitt and lawyer Ludwik Wolski, on the one hand, and the coryphaeus of the Krakow school of history, Józef Szujski, on the other, didn't concern only the interpretation of the past. The exchange of views regarding the proper interpretation of the past applied as much to the past as it did to the present, touching on the issues of current policies. The author shows that the controversy occasioned by Szujski's characterization of the Lelevel school of history as a 'priestess of false historiography' and a 'mistress of false politics' was part of a political debate regarding the position to be taken by the Polish delegation to Vienna during the Eastern Crisis in 1875-1878. A different way of interpreting the national past by the representatives of the Lelevel school of history on the one hand and the members of the Kraków school of history on the other reflected differences concerning the policy carried out by the Polish delegation to the Vienna Council of State.

The polemic under discussion was part of a larger political and ideological dispute which arose between the former participants of the January Uprising after its failure. The national disaster led Szujski to become disappointed with romantic ideals and made him embrace the policy of loyalism towards the Habsburg Monarchy. Acting as an informal leader of the loyalist party, Szujski was settling his accounts with the romantic interpretation of the national past. Henryk Schmitt and Ludwik Wolski, on the other hand, clinging to their romantic ideals, sought to persuade Szujski to rejoin the liberal ranks (Wolski in Diagnoza). They criticised the monarchical interpretation of Polish historical experience promoted by scholars connected with the Kraków school of history and pointed out the negative consequences of pursuing the 'politics of history' based on the conviction of the self-inflicted fall of the Polish-Lithuanian Commonwealth. It is worth noting that such a distinguished historian as Szujski, caught up in the heat of the controversy, failed to steer clear of advancing contradictory views. He denounced his former democratic beliefs, while at the same time defending them. They were now described as conservative.

Anna Wardzińska jest pracownikiem Archiwum Głównego Akt Dawnych w Warszawie, przygotowuje pracę doktorską na temat demokratycznego środowiska dziennikarskiego we Lwowie w XIX w. E-mail: anna_wardzinska@o2.pl 